\title{
Comparative analysis of $0.1 \%$ cyclosporin A cationic emulsion and $0.05 \%$ cyclosporin A emulsion in murine dry eye cases with different severities
}

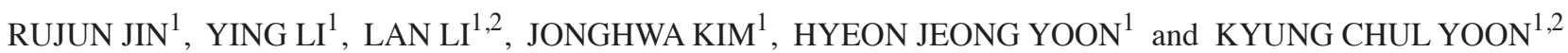 \\ ${ }^{1}$ Department of Ophthalmology, Chonnam National University Medical School and Hospital; \\ ${ }^{2}$ Department of Biomedical Sciences and Centers for Creative Biomedical Scientists at \\ Chonnam National University, Donggu, Gwangju 61469, Republic of Korea
}

Received February 17, 2021; Accepted July 23, 2021

DOI: $10.3892 / \mathrm{etm} .2021 .10797$

\begin{abstract}
Dry eye (DE), especially severe DE (SDE), can cause ocular surface defects and reduce the patient's quality of life. Several clinical studies have shown that $0.1 \%$ cyclosporin A cationic emulsion (CsA CE) could decrease corneal damage. However, no experimental study has reported the effect of $0.1 \%$ CsA CE on SDE. The present study aimed to compare the efficacy of $0.1 \% \mathrm{CsA} \mathrm{CE}$ with that of $0.05 \% \mathrm{CsA}$ emulsion for ocular surface damage and inflammation in the cases of murine DE with different severities. Following exposure to desiccating stress and subcutaneous injection of scopolamine for 5 days, C57BL/6 female mice were divided into SDE and non-SDE (NSDE) groups based on corneal fluorescein staining scores (CFSs). Mice from both groups were topically treated with $0.05 \%$ CsA emulsion or $0.1 \%$ CsA CE for 10 days. The results demonstrated that $0.1 \%$ CsA CE-treated mice in the SDE and NSDE groups exhibited significant improvements in all the clinical and experimental parameters. Furthermore, the CFS of $0.1 \%$ CsA CE-treated mice in the SDE group was lower compared with that of the $0.05 \%$ CsA-treated mice. In addition, in the SDE group, $0.1 \%$ CsA CE-treated mice had significantly lower levels of nuclear factor- $\kappa \mathrm{B}$ activation, inflammatory infiltrations and apoptosis on the ocular surface, and they also exhibited higher conjunctival goblet cell density compared with the $0.05 \% \mathrm{CsA}$-treated mice. In summary, these findings indicated that $0.1 \% \mathrm{CsA} \mathrm{CE}$ was more effective than topical $0.05 \%$ CsA emulsion at improving corneal epithelial injury and decreasing the levels of inflammatory cytokines and $\mathrm{T}$ cells in mice with SDE.
\end{abstract}

Correspondence to: Professor Kyung Chul Yoon, Department of Ophthalmology, Chonnam National University Medical School and Hospital, 42 Jebongro, Donggu, Gwangju 61469, Republic of Korea E-mail: kcyoon@jnu.ac.kr

Key words: severe dry eye, cyclosporin A, cationic emulsion, inflammation, ocular surface damage

\section{Introduction}

Dry eye (DE) is a multifactorial disease of the tear film and ocular surface that is characterized by multiple symptoms, including discomfort, visual disturbance and tear film instability, which may potentially damage the ocular surface (1). DE is accompanied by increased osmolarity of the tear film and inflammation of the ocular surface $(2,3)$. Long-term progression of inflammation at the ocular surface has the potential to aggravate symptoms and signs, resulting in severe DE (SDE). SDE is associated with an increased risk of infection, vision loss and ocular surface epithelial defects (4). Numerous patients with SDE report ocular pain, which may reduce their quality of life due to ocular surface damage $(5,6)$.

At present, topical $0.05 \%$ cyclosporin A (CsA; Restasis ${ }^{\circledR}$; Allergan), an anionic oil in water emulsion possessing anti-inflammatory properties, has demonstrated marked efficacy for DE treatment (7). Following treatment with $0.05 \% \mathrm{CsA}$ emulsion, patients with DE exhibited ameliorated symptoms and improvements in other indicators, including improvements in the ocular surface disease index (OSDI), Schirmer values and corneal fluorescein staining scores (CFS) (8-10). However, in patients with severe inflammatory forms of DE, such as graft-versus-host disease (GVHD) or Sjögren syndrome (SS), the use of $0.05 \% \mathrm{CsA}$ emulsion twice daily was found to have limitations in controlling ocular surface inflammations (11).

In previous clinical studies published over the last decade, marked improvements have been observed for subjective symptoms (i.e., based on the OSDI, Schirmer test, and CFS) in patients with severe keratoconjunctivitis, including GVHD and $\mathrm{SS}$, following treatment with $0.1 \% \mathrm{CsA}$ cationic emulsion (CsA CE; iKervis ${ }^{\circledR}$; Santen Pharmaceutical Co., Ltd.) compared with $0.05 \%$ CsA emulsion (12-14). Although clinical studies have demonstrated that $0.1 \% \mathrm{CsA} \mathrm{CE}$ leads to an improvement in symptoms and indicators in patients following treatment for longer or shorter periods of time, to the best of our knowledge, no study has investigated the effect of $0.1 \%$ CsA CE topical application on ocular surface inflammation and damage in experimental DE (EDE). The aim of the present study was therefore to investigate the therapeutic effects of topical $0.1 \%$ CsA CE treatment on tear film parameters [tear volume and 
tear film break-up time (BUT)], ocular surface damage (via evaluating CFS) and inflammatory properties (i.e., the levels of inflammatory cytokines and T cells) in a murine model of EDE with different severities and to compare these effects with those of topical $0.05 \%$ CsA emulsion treatment.

\section{Materials and methods}

Design of the mouse model and in vivo experiments. The research protocol was approved by the Chonnam National University School Research Institutional Animal Care and Use Committee (approval no. CNU IACUC-H-2018-73). EDE was induced by desiccating stress (exposure to an air draft all day; $30 \%$ ambient humidity) and subcutaneous injection of scopolamine $(0.5 \mathrm{mg}, 0.2 \mathrm{ml}$; MilliporeSigma) three times a day (at 9 a.m., 1:30 p.m. and 6 p.m.) as previously described $(15,16)$. In the present study, 8-week-old female C57BL/6 mice (weight, 16.0 $2 \mathrm{~g}$ ) were used, and EDE was induced by desiccating stress (exposure to an air draft all day and 30\% ambient humidity) and subcutaneous injection of scopolamine (0.5 mg, $0.2 \mathrm{ml}$; MilliporeSigma) three times a day (at 9 a.m., 1:30 p.m. and 6 p.m.) as previously described $(15,16)$. A total of 54 EDE-induced mice were divided into two groups based on the CFSs: i) The SDE group $(12 \leq \mathrm{CFS} \leq 16)$; and ii) the NSDE group $(0 \leq \mathrm{CFS}<12$; Fig. 1). In addition, $27 \mathrm{EDE}$-induced mice from each group were separated into three subgroups of 9 mice according to topical treatment as follows: i) EDE group, where mice were exposed to desiccating stress and received no eye drops; ii) the $0.05 \%$ CsA group, where EDE mice were treated with $2 \mu 10.05 \%$ CsA emulsion twice daily (Restasis ${ }^{\circledR}$; Allergan); iii) the $0.1 \%$ CsA CE group, where EDE mice were treated with $2 \mu 10.1 \%$ CsA CE once daily (iKervis ${ }^{\circledR}$; Santen). The mice not exposed to desiccating stress were used as untreated (UT) controls.

The mice in all treatment groups, except for the UT group, received scopolamine injections. Nine animals in each subgroup were used for clinical and experimental analysis and no animal was found dead before euthanasia. Tear film parameters (tear volume and tear film BUT) and CFSs were evaluated after 5 and 10 days of CsA application. After assessment of the clinical parameters, mice were deeply anesthetized with $3 \%$ sevoflurane and intraperitoneal injection of sodium pentobarbital $(50 \mathrm{mg} / \mathrm{kg})$. Transcardial perfusion was subsequently performed with $4 \%$ paraformaldehyde in phosphate buffer ( $\mathrm{pH}$ 7.4) for euthanasia. Animals were euthanized by experienced experts and when needed, medications and supplies were available, minimizing pain and stress for the animals. Euthanasia was performed in accordance with the AVMA Animal Euthanasia Guidelines: 2020 Edition (https://www.avma.org). Following euthanasia, animal death was confirmation by the absence of cardiovascular and respiratory movements. Western blotting, multiplex immunobead assay and flow cytometric analysis, histological analysis and TUNEL staining were performed at day 15 after initiation of the treatment. During these experiments, animals were treated in accordance with ARVO Statement for the Use of Animals in Ophthalmic and Vision Research, and animal movement, food and water intake were not restricted (https://www.arvo. org/About/policies/statement-for-the-use-of-animals-in-oph thalmic-and-vision-research/\#three). Experiments involving
EDE induction and CsA application lasted 15 consecutive days and the experiment was repeated three times. In addition, all clinical and laboratory analyzes were performed after each experiment. As all experiments were repeated 3 times, a total of 216 mice were used within the present study.

Evaluation of tear film parameters and corneal epithelial damage. Tear volume was measured using phenol red impregnated cotton threads (Zone-Quick ${ }^{\mathrm{TM}}$; Oasis Medical, Inc.), and the threads were placed in the lateral canthus for $20 \mathrm{sec}$ as previously described $(17,18)$. The length of the wet red thread was measured in $\mathrm{mm}$ under a photomicroscope (light microscope; magnification, x1; SMZ 1500; Nikon Corporation).

After allowing $1 \mu \mathrm{l}$ of $1 \%$ sodium fluorescein to fall into the inferior conjunctival sac for $20 \mathrm{sec}$, the ocular surface was washed with PBS and the tear film BUT (in sec) was recorded using slit lamp biomicroscopy (BQ-900; Haag-Streit Diagnostics) under cobalt blue light. The cornea was distributed into four parts, which were scored separately. The CFSs were calculated according to a 4 point scale and added together to obtain a final score (range, 0-16) as previously described (19).

Western blotting. The expression of the nuclear factor (NF)- $\kappa \mathrm{B}$ p65 protein was determined using western blotting. Proteins were extracted from the conjunctival tissues (4 eyes per group) using lysis buffer (RIPA buffer; GeneAll Biotechnology Co., Ltd.) supplemented with a protease inhibitor cocktail (cat. no. 11836153001; Roche Diagnostics $\mathrm{GmbH}$ ) on ice, and lysates were centrifuged at $25,200 \mathrm{x}$ for $10 \mathrm{~min}$ at $4^{\circ} \mathrm{C}$, as previously described (20). Proteins $(20 \mu \mathrm{g})$ were separated by $12 \%$ SDS-PAGE and were transferred onto PVDF membranes. Membranes were washed with TBST-Tween-20 [TBST; $10 \mathrm{mM}$ Tris- $\mathrm{HCl}$ (pH 7.6), $150 \mathrm{mM} \mathrm{NaCl}$ and $0.05 \%$ Tween-20] and blocked with 5\% skimmed milk in TBST for $1 \mathrm{~h}$ at room temperature. Membranes were incubated for $2 \mathrm{~h}$ at room temperature with the following primary antibodies: Rabbit polyclonal antibody against NF- $\mathrm{B}$ p65 (cat. no. ab16502; Abcam; diluted by 1:1,000), rabbit anti-phosphorylated NF-кB p65 (cat. no. ab76302; Abcam; diluted by 1:500) and anti- $\beta$-actin (cat. no. ab8227; Abcam; diluted by 1:1,000). The membranes were washed three times with $1 \mathrm{X}$ TBST buffer for 5 min and incubated with secondary antibodies goat anti-rabbit IgG H\&L (cat. no. ab205718; Abcam; diluted by 1:5,000, $1: 5,000$, and 1:10,000 for visualization of NF- $\kappa \mathrm{B}$ p65, phosphorylated $\mathrm{NF}-\kappa \mathrm{B}$ p65 and $\beta$-actin antibodies, respectively) diluted in $1 \mathrm{X}$ TBST for $60 \mathrm{~min}$ at room temperature. After incubation, membranes were washed five times with TBST for 5 min. Enhanced chemiluminescence system (ECL Blotting Analysis System; Cytiva) was used to detect the signal on the membrane. The data were analyzed via densitometry (Alliance MINI HD9; UVItec Ltd.) and normalized to the expression of the internal control $\beta$-actin.

Multiplex immunobead assay. The levels of tumor necrosis factor- $\alpha$ (TNF- $\alpha$ ), interferon- $\gamma$ (IFN- $\gamma$ ), interleukin (IL)-6, IL-17 and IL-21 in mice conjunctiva (six eyes per group) were evaluated using MILLIPLEX MAP Mouse Cytokine/Chemokine Magnetic Bead Panel - Immunology Multiplex Assay kit (all from Milliplex ${ }^{\circledR}$; MilliporeSigma; cat. no. MCYTOMAG-70K) and the Luminex 200 detection 
method (Luminex Corporation) as previously described (16). The conjunctival tissues $(10 \mathrm{mg})$ were collected, pooled and lysed in TissueLyser lysis buffer (Qiagen, Inc.) containing protease inhibitors (cat. no. 11836153001; Roche Diagnostics $\mathrm{GmbH}$ ) for $30 \mathrm{~min}$ on ice. The extracts were subsequently centrifuged at $14,000 \mathrm{x}$ g for $15 \mathrm{~min}$ at $4^{\circ} \mathrm{C}$. After centrifugation, the samples were added to a 96 -well plate $(25 \mu 1 /$ well $)$ and incubated overnight at $4^{\circ} \mathrm{C}$ in the dark with $25 \mu \mathrm{l} 1 \mathrm{X}$ beads coupled to mouse cytokine/chemokine-specific antibodies. Serial dilutions of each cytokine/chemokine were also performed on the same plate to generate a standard curve. The following day, the beads were washed and mixed with $25 \mu 11 \mathrm{X}$ biotinylated secondary cytokine/chemokine antibody mixture for $1 \mathrm{~h}$ at room temperature, followed by a wash and subsequent incubation with $25 \mu \mathrm{l}$ streptavidin-phycoerythrin for $30 \mathrm{~min}$ at room temperature (both steps performed in the dark). After a final wash, the beads were resuspended in $150 \mu \mathrm{l}$ sheath fluid assay buffer. The reactions were detected after addition of streptavidin-phycoerythrin using an analysis system (xPONENT; Luminex Corporation). The concentrations of cytokines in the tissues were calculated using standard curves of known concentrations of recombinant mouse cytokines.

Flow cytometric analysis. The percentages of $\mathrm{CD}^{+} \mathrm{IFN}-\gamma^{+}$ $\mathrm{T}$ cells and $\mathrm{CD} 4^{+} \mathrm{IL}-17^{+} \mathrm{T}$ cells in mice cornea and conjunctiva (6 eyes per group) were evaluated using flow cytometric analysis as previously described (21). Tissues from each group were surgically removed and immersed in PBS. Subsequently, samples were torn apart with scissors and incubated with 0.5 $\mathrm{mg} / \mathrm{ml}$ collagenase type D (Roche Applied Science) under agitation at $37^{\circ} \mathrm{C}$ for $45 \mathrm{~min}$. The samples were disrupted by grinding using a syringe plunger and subsequently passed through a cell strainer with a pore size of $100 \mu \mathrm{m}$. Cells were then centrifuged for $7 \mathrm{~min}$ at $450 \mathrm{x}$ g at $4^{\circ} \mathrm{C}$. Subsequently, samples were resuspended in PBS containing $1 \%$ BSA, then $2 \mu \mathrm{l}$ of fluorescein-conjugated anti-CD4 antibody $(0.5 \mathrm{mg} / \mathrm{ml}$; cat. no. 553651; BD Biosciences), phycoerythrin-conjugated anti-IFN- $\gamma$-antibody $(0.5 \mathrm{mg} / \mathrm{ml}$; cat. no. 554412; BD Biosciences) and phycoerythrin-conjugated anti-IL-17 antibody $(0.5 \mathrm{mg} / \mathrm{ml}$; cat. no. 561020 ; BD Biosciences) were added for an incubation at $4^{\circ} \mathrm{C}$ for $30 \mathrm{~min}$. Phycoerythrin-conjugated rat $\mathrm{IgG}$ isotype (BD Biosciences) was used as the control. The percentage of $\mathrm{CD}^{+}{ }^{+} \mathrm{IFN}-\gamma^{+}$and $\mathrm{CD} 4^{+} \mathrm{IL}-17^{+} \mathrm{T}$ cells were evaluated using a FACSCalibur cytometer with CellQuest software (version 5.2.1; BD Biosciences).

Histological analysis. Mice eye and adnexa were surgically excised, fixed in $4 \%$ paraformaldehyde overnight at $4^{\circ} \mathrm{C}$ and embedded in paraffin. Sections (thickness, $6 \mu \mathrm{m}$ ) were stained with Periodic Acid-Schiff reagent (cat. no. 395B-1 KT; MilliporeSigma; Merck KGaA) for 15 min at room temperature, and those obtained from four animals in each group were subsequently examined and imaged using a light microscope (magnification, x10; Olympus Corporation) equipped with a digital camera. Goblet cell density in the superior and inferior conjunctiva was measured in three sections from each eye using Image-Pro version 10.0.5 (Medial Cybernetics, Inc.) and was expressed as the number of goblet cells per $100 \mu \mathrm{m}$.
TUNEL staining. A TUNEL assay was used to detect the 3 'hydroxyl ends of the fragmented DNA as an early event in the apoptotic cascade and to identify apoptotic cells. Mice eye and adnexa were surgically excised, fixed in $4 \%$ paraformaldehyde overnight at $4^{\circ} \mathrm{C}$ and embedded in paraffin. After deparaffinization and washing, the samples were rehydrated by sequential immersion. Graded ethanol washes (100, 95, 85,70 and 50\%) were performed at room temperature for 3 min each. After rehydration, the tissues were immersed in a 4\% methanol-free formaldehyde solution in PBS for $15 \mathrm{~min}$ at room temperature to fix the tissue. The slides were then incubated in $20 \mu \mathrm{g} / \mathrm{ml}$ proteinase $\mathrm{K}$ for $10 \mathrm{~min}$ at room temperature, before being rinsed with PBS for $5 \mathrm{~min}$. The samples were subsequently incubated in terminal deoxynucleotidyl transferase, recombinant, enzyme containing equilibration buffer and nucleotide mix for $60 \mathrm{~min}$ at $37^{\circ} \mathrm{C}$ in the dark. The reaction was terminated by adding $2 \mathrm{X}$ saline-sodium citrate buffer for $15 \mathrm{~min}$. The samples were washed three times with PBS for 5 min and stained with VECTASHIELD ${ }^{\circledR}$ and DAPI. Staining was evaluated using the DeadEnd ${ }^{\mathrm{TM}}$ Fluorometric TUNEL System (Promega Corporation) according to the manufacturer's instructions. The images were observed on a Leica TCS SP5 AOBS laser scanning confocal microscope (Zeiss $\mathrm{GmbH}$ ) under an LSM 800 10x (N.A. 0.4) oil objective. Cell images were obtained separately with the following fluorescence excitation and emission settings: Excitation wavelengths at 405 and $488 \mathrm{~nm}$ and emission wavelengths between 424-472 and 502-550 nm for TUNEL assay and DAPI staining, respectively. TUNEL positive cells and nuclear staining of cells with DAPI in the cornea were viewed under a fluorescent microscope (magnification, $\mathrm{x} 20$ ).

Statistical analyses. SPSS software (version 18.0; SPSS, Inc.) was used for all statistical analyses. Data were presented as the means \pm standard deviation. The normal distribution of the data was verified using Kolmogorov-Smirnov test. Statistical differences for tear volume, tear film BUT and CSS among the groups were determined using one-way ANOVA tests followed by Dunnett's post hoc tests (sphericity assumptions were evaluated with a Mauchly's test, and in the case of violation, the data were adjusted with an Epsilon Greenhouse-Geisser statistic). A Kruskal-Wallis test followed by a Dunn's multiple comparisons post-hoc test was used to compare the expression levels of NF- $\mathrm{BB}$, the cytokine levels and the goblet cell density and apoptotic cell density data derived from the flow cytometric analysis experiments between the groups. $\mathrm{P}<0.05$ was considered to indicate a statistically significant difference.

\section{Results}

Tear film parameters on the ocular surface. Mean tear volumes of the SDE group at 5 and 10 days were $0.043 \pm 0.005 \mu \mathrm{l}$ and $0.042 \pm 0.004 \mu \mathrm{l}$ in UT mice, $0.023 \pm 0.004 \mu 1$ and $0.02 \pm 0.004 \mu \mathrm{l}$ in EDE mice, $0.027 \pm 0.004 \mu 1$ and $0.03 \pm 0.005 \mu 1$ in $0.05 \%$ CsA-treated mice, and $0.03 \pm 0.003 \mu 1$ and $0.032 \pm 0.004 \mu 1$ in $0.1 \%$ CsA CE-treated mice, respectively. In addition, mean tear volumes of the NSDE group at 5 and 10 days were $0.044 \pm 0.004 \mu \mathrm{l}$ and $0.042 \pm 0.003 \mu \mathrm{l}$ in UT mice, $0.025 \pm 0.004 \mu \mathrm{l}$ and $0.020 \pm 0.004 \mu 1$ in EDE mice, $0.028 \pm 0.005 \mu 1$ and 


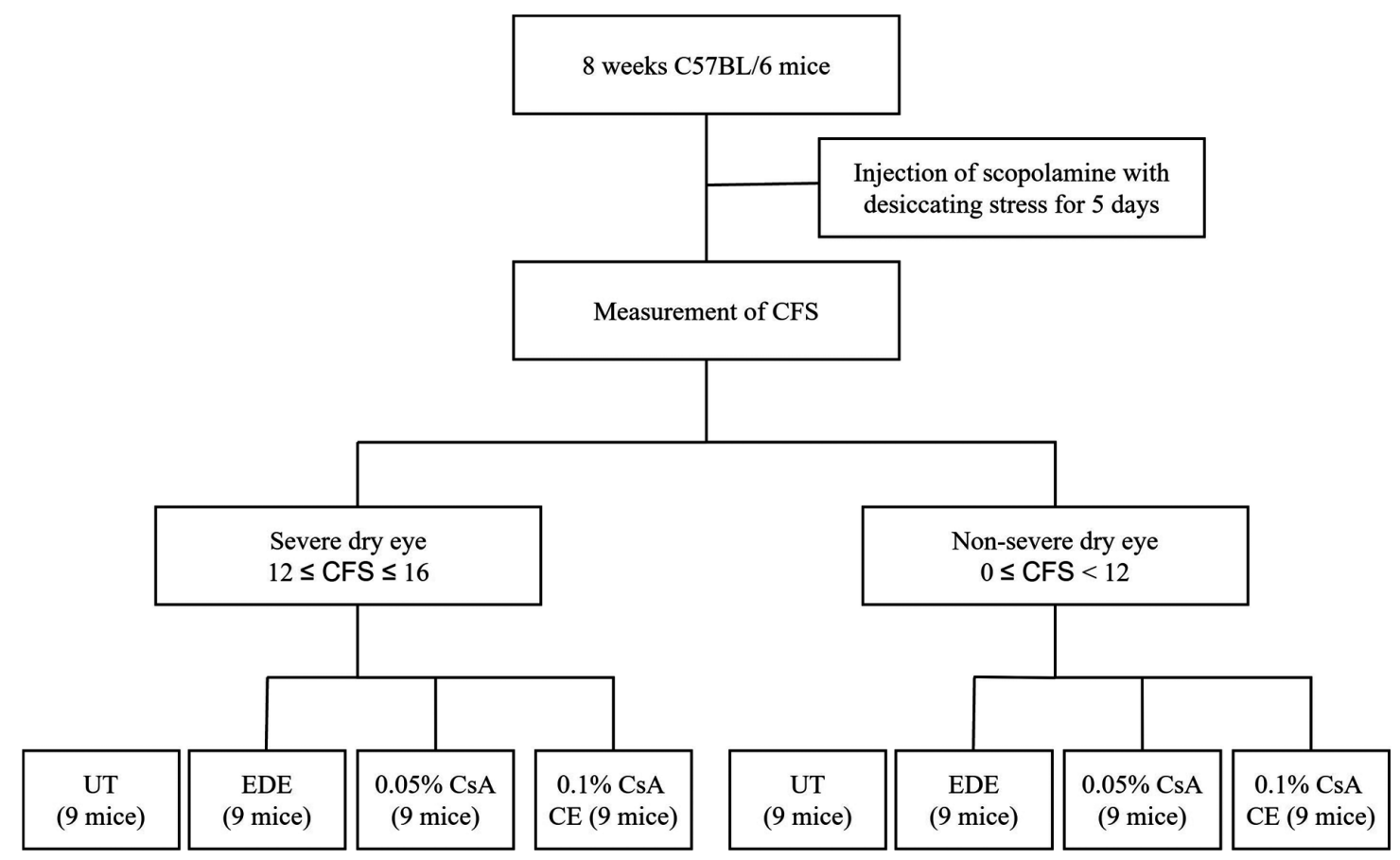

Figure 1. Study design for the SDE and NSDE groups. The mice were divided into the SDE and NSDE groups based on CFSs, after 5 days of EDE induction. Euthanasia was performed at day 15 after initiation of the treatment, and corneal and conjunctival tissues were collected for analysis. SDE, severe dry eye; NSDE, non-severe dry eye; CFS, corneal fluorescein staining; CsA, cyclosporin A; CE, cationic emulsion; UT, untreated; EDE, experimental dry eye.

$0.031 \pm 0.004 \mu \mathrm{l}$ in $0.05 \%$ CsA-treated mice, and $0.031 \pm 0.003 \mu \mathrm{l}$ and $0.033 \pm 0.005 \mu \mathrm{l}$ in $0.1 \% \mathrm{CsA}$ CE-treated mice, respectively (Fig. 2A). Mice treated with $0.1 \%$ CsA CE in the SDE and NSDE groups exhibited a significant increase in tear volume compared with EDE mice at 5 and 10 days, whereas $0.05 \%$ CsA-treated mice in both groups had an improvement in tear volume at 10 days (all $\mathrm{P}<0.05)$. No significant differences were observed between $0.05 \% \mathrm{CsA}$ and $0.1 \%$ CsA CE-treated mice from the two groups.

The mean tear film BUTs in the SDE group at 5 and 10 days were $2.18 \pm 0.10$ and $2.07 \pm 0.21 \mathrm{sec}$ in UT mice, $1.07 \pm 0.18$ and $0.85 \pm 0.10 \mathrm{sec}$ in EDE mice, $1.18 \pm 0.19$ and $1.24 \pm 0.16 \mathrm{sec}$ in $0.05 \% \mathrm{CsA}$-treated mice, and $1.26 \pm 0.19$ and $1.32 \pm 0.15 \mathrm{sec}$ in $0.1 \% \mathrm{CsA}$ CE-treated mice, respectively. Tear film BUTs in the NSDE group at 5 and 10 days were $2.32 \pm 0.25$ and $2.16 \pm 0.16 \mathrm{sec}$ in the UT mice, $1.14 \pm 0.26$ and $0.97 \pm 0.14 \mathrm{sec}$ in the EDE mice, $1.27 \pm 0.12$ and $1.30 \pm 0.08$ sec in the $0.05 \% \mathrm{CsA}$ mice, and $1.29 \pm 0.18$ and $1.34 \pm 0.09$ sec in $0.1 \%$ CsA CE-treated mice, respectively (Fig. 2B). Mice treated with $0.1 \%$ CsA CE in the NSDE and SDE groups had a significantly higher tear film BUT compared with EDE treated mice at 5 and 10 days (all $\mathrm{P}<0.05$ ); however, no significant differences were identified with $0.05 \%$ CsA-treated mice. The $0.05 \%$ CsA-treated mice in the two groups did present with an increased tear film BUT compared with EDE mice at 10 days (all $\mathrm{P}<0.05)$.

Ocular surface damages. The mean CFSs in the SDE group for UT, EDE, $0.05 \% \mathrm{CsA}$ and $0.1 \%$ CsA CE-treated mice at days 5 and 10 were $2.17 \pm 0.72$ and $2.58 \pm 0.67,13.92 \pm 1.17$ and $15.17 \pm 0.58,11.75 \pm 1.71$ and $10.58 \pm 1.56$, and $10.25 \pm 1.87$ and $8.83 \pm 1.19$, respectively. Mean CFSs in the NSDE group at 5 and 10 days were $1.92 \pm 0.29$ and $2.58 \pm 0.79$ (UT mice), $11.50 \pm 1.57$ and $13.17 \pm 1.53$ (EDE mice), 8.67 \pm 1.23 and $7.75 \pm 0.97(0.05 \%$ CsA-treated mice), and $8.17 \pm 1.27$ and $7.17 \pm 0.84(0.1 \%$ CsA CE-treated mice), respectively (Fig. 2C and D). Mice treated with $0.1 \% \mathrm{CsA} \mathrm{CE}$ and $0.05 \% \mathrm{CsA}$ in both groups exhibited a significantly decreased CFS compared with EDE mice at 5 and 10 days (all $\mathrm{P}<0.05$ ). In addition, in the SDE group, $0.1 \%$ CsA CE-treated mice had a significantly lower CFS compared with $0.05 \%$ CsA-treated mice at 5 and 10 days (both $\mathrm{P}<0.05$ ).

Expression of $N F-\kappa B$ in mice conjunctiva. To investigate the involvement of $\mathrm{NF}-\kappa \mathrm{B}$ activation in the conjunctiva, the expres-

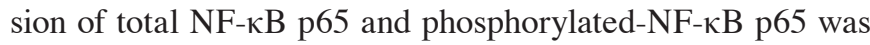
evaluated in conjunctival tissues (Fig. 3). CsA-treated mice in the SDE and NSED groups showed a decreased expression of $\mathrm{NF}-\kappa \mathrm{B}$ in the conjunctiva. Furthermore, in the SDE group, mice treated with $0.1 \% \mathrm{CsA} C E$ had a lower $\mathrm{NF}-\kappa \mathrm{B}$ expression compared with those treated with $0.05 \% \mathrm{CsA}$ (all $\mathrm{P}<0.05)$.

Inflammatory cytokine levels in conjunctival tissues. Significantly decreased levels of TNF- $\alpha$, IL-6 and IL-17 were observed in the conjunctiva of $0.1 \% \mathrm{CsA} \mathrm{CE}$ and $0.05 \%$ CsA-treated mice compared with EDE mice (all $\mathrm{P}<0.05$ ). In the SDE group, mice treated with $0.1 \%$ CsA CE exhibited significantly lower IL- 6 and IL-17 levels compared with $0.05 \%$ CsA-treated mice (both $\mathrm{P}<0.05$; Fig. 4A-J).

Flow cytometric analysis. The percentage of $\mathrm{CD} 4^{+} \mathrm{IFN}-\gamma^{+}$and $\mathrm{CD} 4^{+} \mathrm{IL}-17^{+} \mathrm{T}$ cells in the cornea and conjunctiva of the SDE and NSDE groups from the UT, EDE, $0.05 \% \mathrm{CsA}$, and $0.1 \%$ CsA CE mice treatment groups are presented in Figs. 5 and 6. Mice treated with $0.1 \% \mathrm{CsA} \mathrm{CE}$ and $0.05 \% \mathrm{CsA}$ in both groups showed a decreased percentage of CD $4^{+}$IFN- $\gamma^{+}$and 

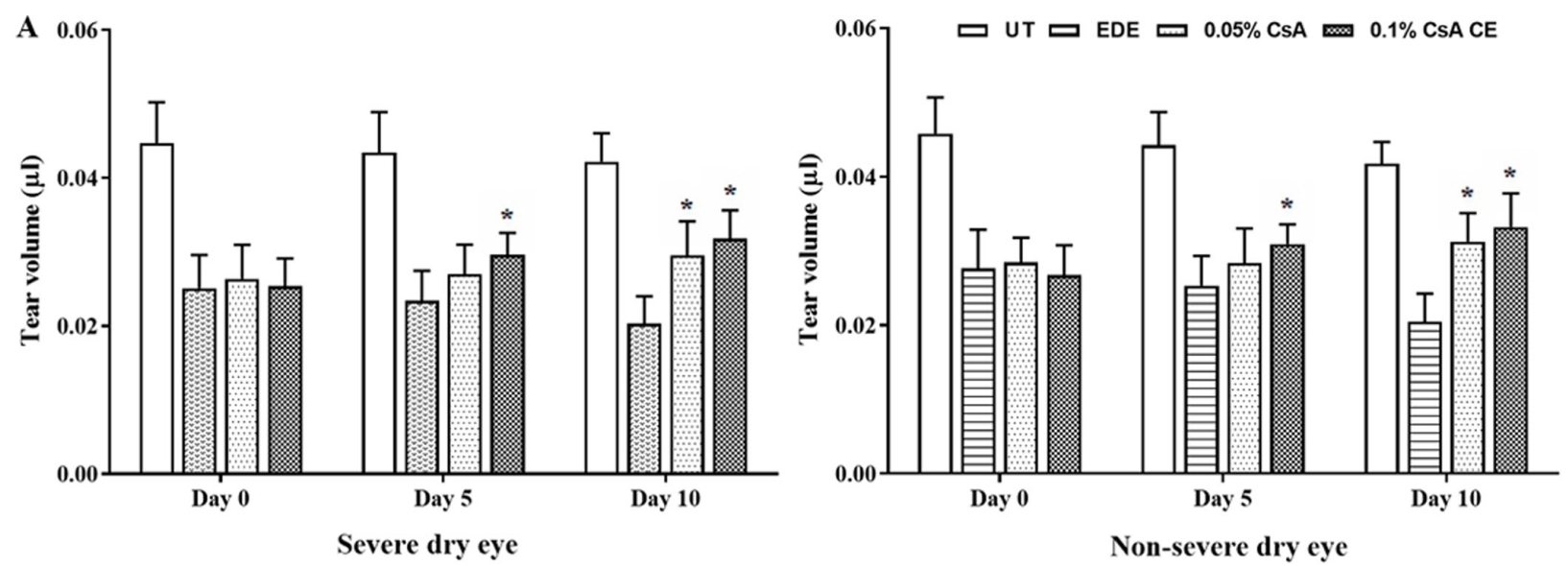

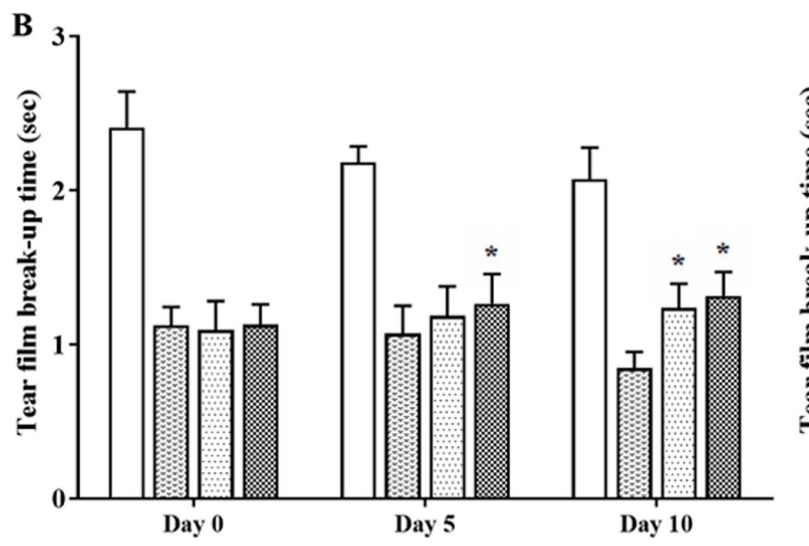

Severe dry eye

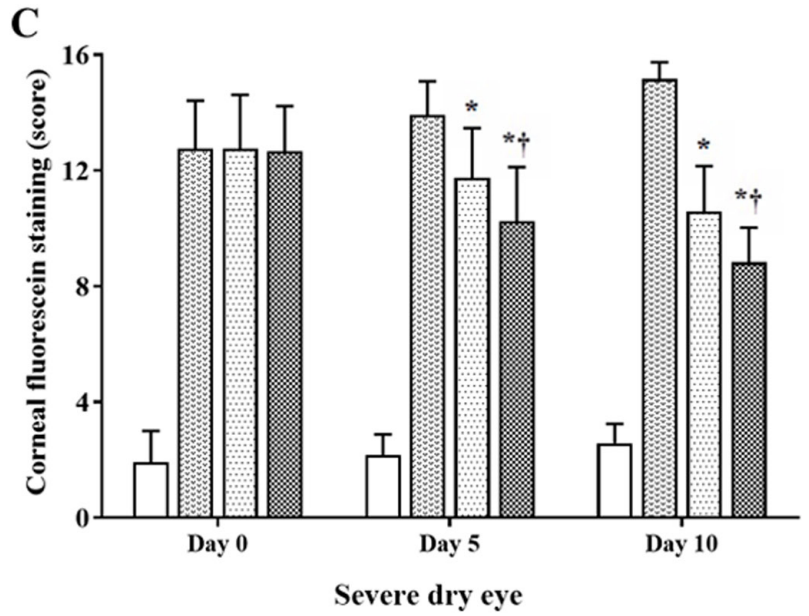

D

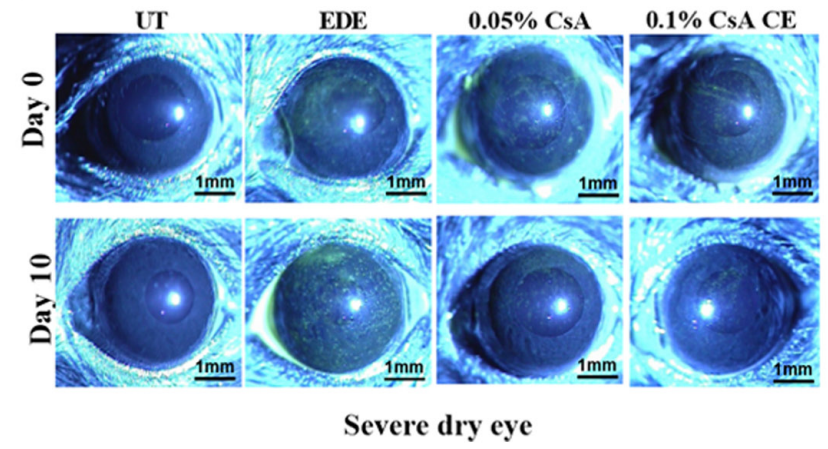

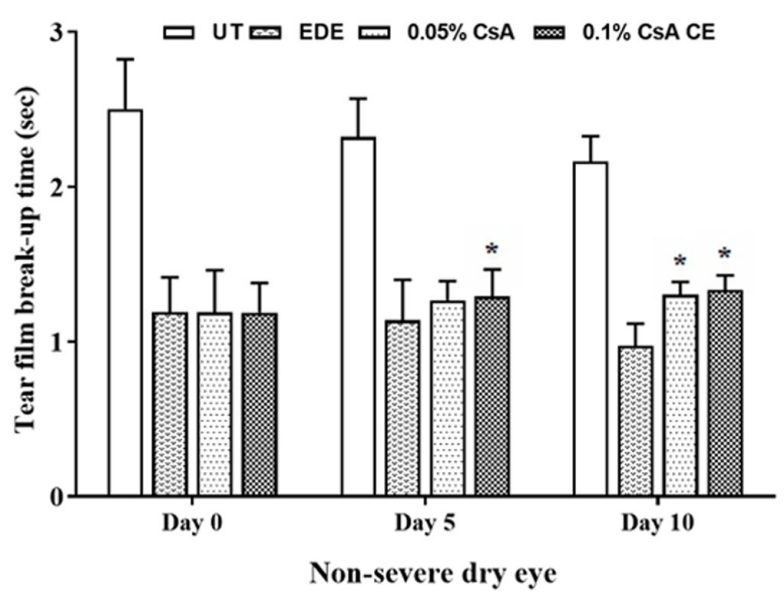
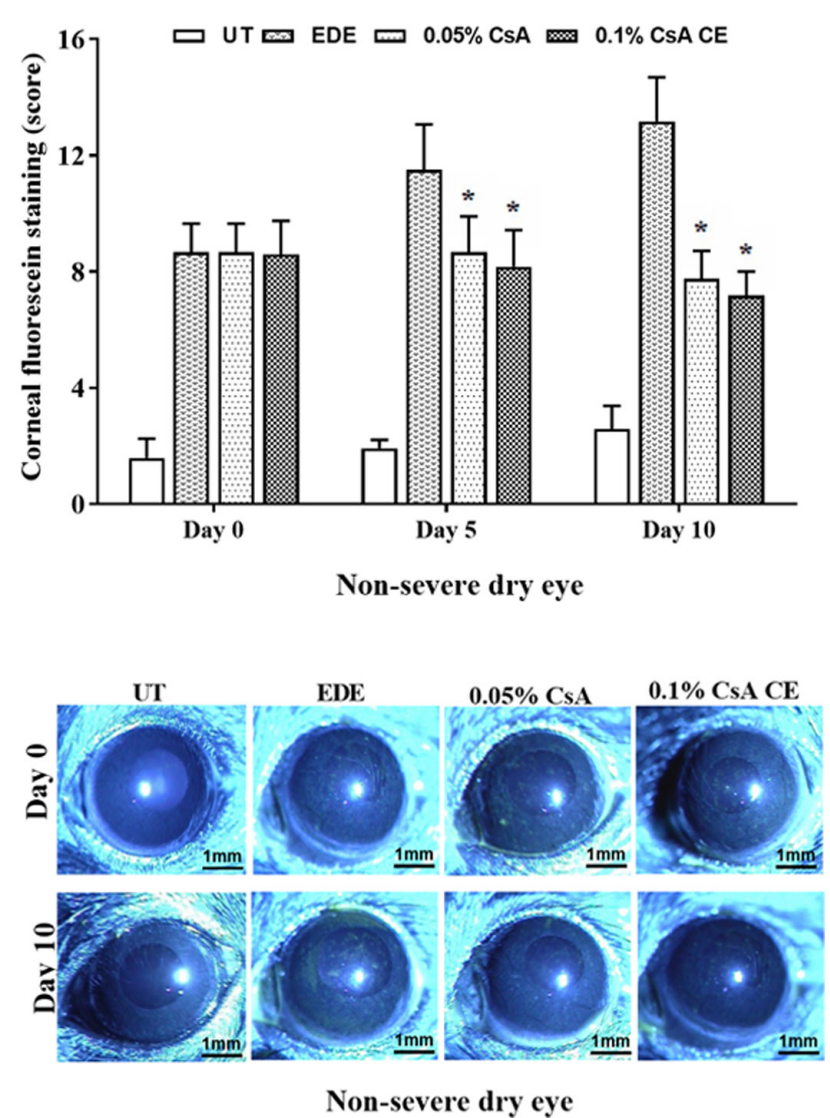

Figure 2. Analysis of clinical parameters. (A) Mean tear volume, (B) tear film break-up time, (C) corneal fluorescein staining scores and (D) representative images of corneal fluorescein staining in UT, EDE, 0.05\% CsA emulsion-treated and $0.1 \%$ CsA CE-treated mice of the severe dry eye and non-severe dry eye groups at 0 and 10 days. " $\mathrm{P}<0.05$ vs. EDE' 'P $\mathrm{P}<0.05$ vs. $0.05 \%$ CsA. UT, untreated control; EDE, experimental dry eye; CsA, cyclosporin A; CE, cationic emulsion. 
A

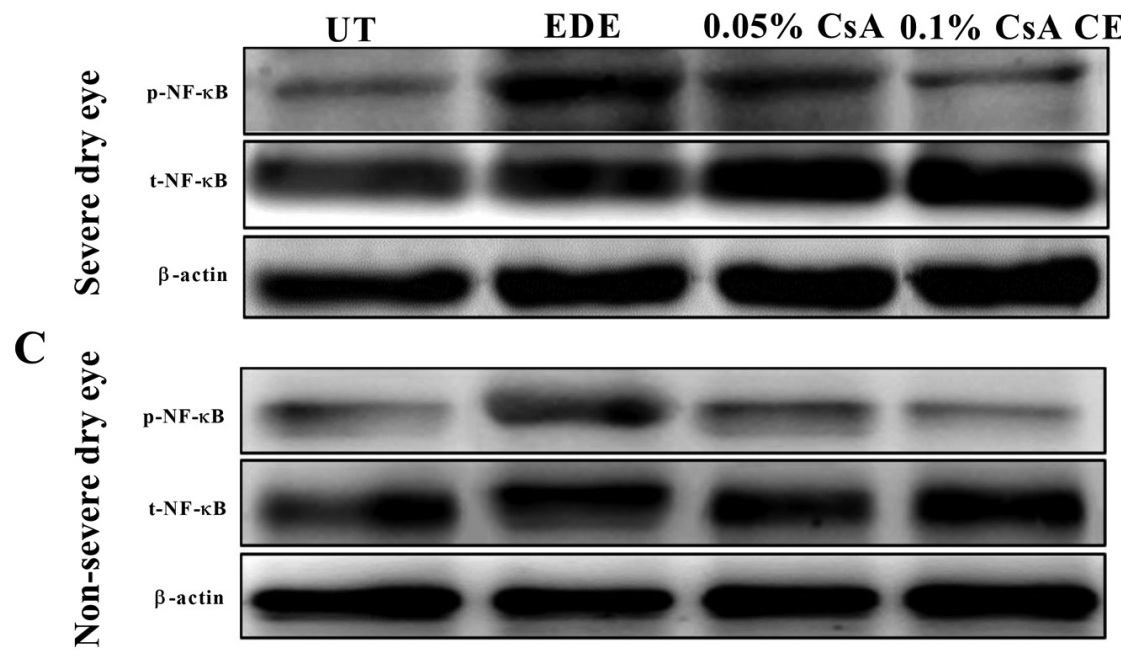

B Severe dry eye

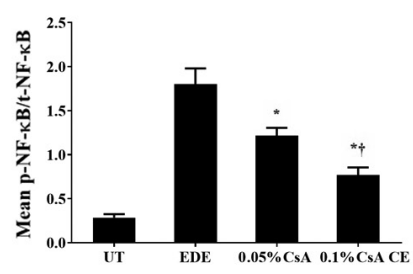

D

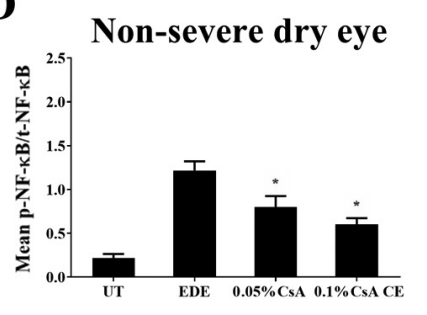

Figure 3. Western blotting analysis for p-NF- $\mathrm{kB} / \mathrm{t}-\mathrm{NF}-\mathrm{\kappa B}$ expression in UT, EDE, $0.05 \%$ CsA emulsion-treated and $0.1 \%$ CsA CE-treated mice of the (A) severe dry eye and (C) non-severe dry eye groups at 10 days. (B and D) Relative protein expression of NF- $\mathrm{kB}$ in the conjunctiva. ${ }^{*} \mathrm{P}<0.05$ vs. EDE; ${ }^{\circ} \mathrm{P}<0.05$ vs. $0.05 \%$

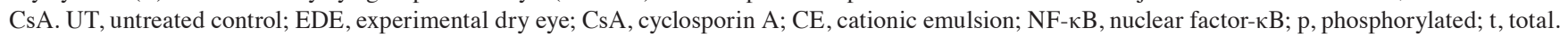
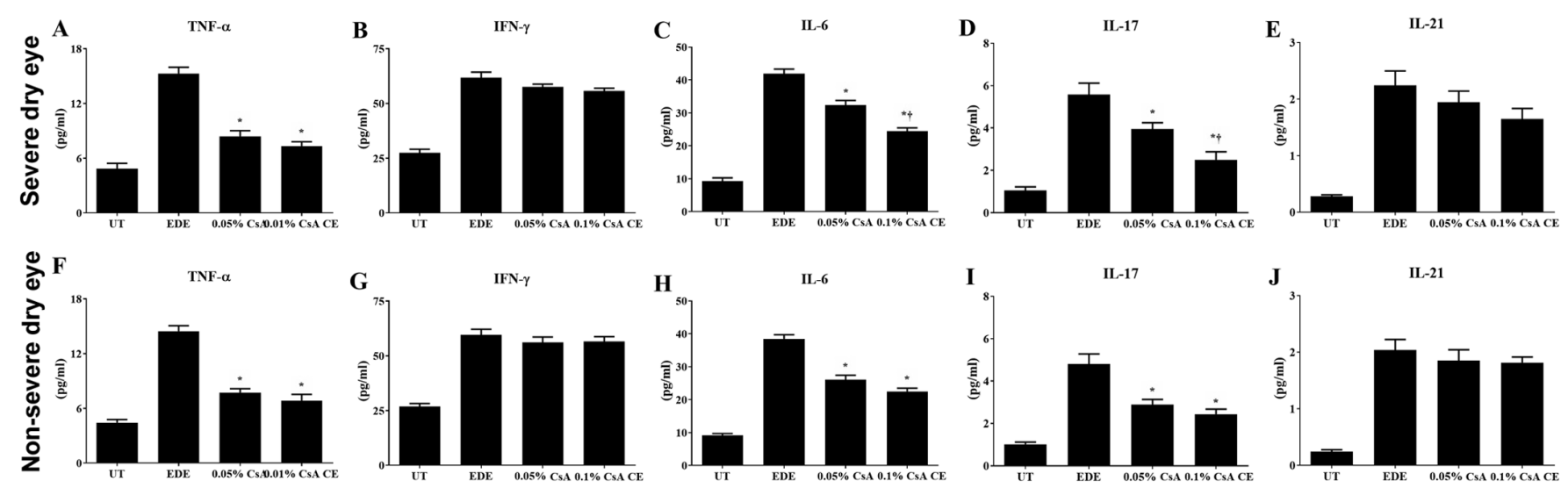

Figure 4. Multiplex immunobead assay for inflammatory levels. Levels of TNF- $\alpha$, IFN- $\gamma$, IL-6, IL-17, and IL-21 in the conjunctiva in UT, EDE, $0.05 \%$ CsA emulsion and $0.1 \%$ CsA CE-treated mice from the (A-E) severe dry eye and (F-J) non-severe dry eye groups at day 10 . " $\mathrm{P}<0.05$ vs. EDE; ${ }^{\dagger} \mathrm{P}<0.05$ vs. $0.05 \%$ CsA. UT, untreated control; EDE, experimental dry eye; CsA, cyclosporin A; CE, cationic emulsion; TNF- $\alpha$, tumor necrosis factor- $\alpha$; IFN, interferon- $\gamma$; IL, interleukin.

$\mathrm{CD} 4{ }^{+} \mathrm{IL}-17^{+} \mathrm{T}$ cells at 10 days (all $\left.\mathrm{P}<0.05\right)$. In addition, in the SDE group, $0.1 \%$ CsA CE-treated mice had significantly lower percentages of $\mathrm{CD} 4^{+} \mathrm{IFN}-\gamma^{+}$and $\mathrm{CD} 4^{+} \mathrm{IL}-17^{+} \mathrm{T}$ cells compared with $0.05 \%$ CsA-treated mice (all $\mathrm{P}<0.05$ ).

Conjunctival gobletcell density. Mean gobletcell densities in the SDE group for UT, EDE, $0.05 \% \mathrm{CsA}$ and $0.1 \% \mathrm{CsA}$ CE-treated mice were $59.00 \pm 7.85$ cells $/ 50 \mu \mathrm{m}, 15.83 \pm 3.60$ cells $/ 50 \mu \mathrm{m}$, $31.67 \pm 6.12$ cells $/ 50 \mu \mathrm{m}$ and $47.17 \pm 6.24$ cells $/ 50 \mu \mathrm{m}$, respectively (Fig. 7A and B). Mean goblet cell densities in the NSDE group were $58.83 \pm 6.94$ cells $/ 50 \mu \mathrm{m}, 27.33 \pm 4.89$ cells $/ 50 \mu \mathrm{m}$, $43.00 \pm 5.69$ cells $/ 50 \mu \mathrm{m}$ and $44.33 \pm 6.35$ cells $/ 50 \mu \mathrm{m}$ for the UT, EDE, $0.05 \% \mathrm{CsA}$ and $0.1 \% \mathrm{CsA} \mathrm{CE}$ mice treatment groups, respectively (Fig. 7C and D). Mice treated with CsA CE in the SDE and NSDE groups showed a significantly increased density of conjunctival goblet cells compared with EDE mice (all $\mathrm{P}<0.05)$. Furthermore, in the SDE group, mice treated with $0.1 \%$ CsA CE exhibited significantly higher conjunctival goblet cell densities compared with those treated with $0.05 \%$ CsA $(\mathrm{P}<0.05)$.
TUNEL staining. Mean apoptotic cell counts in the SDE group for UT, EDE, $0.05 \% \mathrm{CsA}$, and $0.1 \%$ CsA CE-treated mice were $2.00 \pm 0.89$ cells $/ 50 \mu \mathrm{m}, 18.00 \pm 3.23$ cells $/ 50 \mu \mathrm{m}$, $12.17 \pm 2.86$ cells $/ 50 \mu \mathrm{m}$ and $8.17 \pm 1.72$ cells $/ 50 \mu \mathrm{m}$ in the cornea, and $5.00 \pm 2.04$ cells $/ 50 \mu \mathrm{m}, 54.83 \pm 8.59$ cells $/ 50 \mu \mathrm{m}$, $34.00 \pm 7.16$ cells $/ 50 \mu \mathrm{m}$ and $22.00 \pm 5.14$ cells $/ 50 \mu \mathrm{m}$ in the conjunctiva, respectively (Fig. 8A, C and D). Apoptotic cell counts in the NSDE group were $1.83 \pm 1.17$ cells $/ 50 \mu \mathrm{m}$ and $2.33 \pm 1.03$ cells $/ 50 \mu \mathrm{m}$ (UT group), $13.17 \pm 2.40$ cells $/ 50 \mu \mathrm{m}$ and $37.83 \pm 6.68$ cells $/ 50 \mu \mathrm{m}$ (EDE group), $9.00 \pm 2.00$ cells $/ 50 \mu \mathrm{m}$ and $17.50 \pm 4.46$ cells $/ 50 \mu \mathrm{m}(0.05 \% \mathrm{CsA}$-treated group), and $7.00 \pm 2.37$ cells $/ 50 \mu \mathrm{m}$ and $10.83 \pm 1.72$ cells $/ 50 \mu \mathrm{m}(0.1 \%$ CsA CE-treated group) in the cornea and conjunctiva, respectively (Fig. 8B E and F). Mice treated with CsA in the SDE and NSDE groups showed a significantly decreased numbers of apoptotic cells in the corneal and conjunctival tissues compared with those in the EDE group. Furthermore, in the SDE group, mice treated with $0.1 \%$ CsA CE showed lower numbers of apoptotic cells in the cornea and conjunctiva compared with those treated with $0.05 \%$ CsA (all $\mathrm{P}<0.05$ ). 

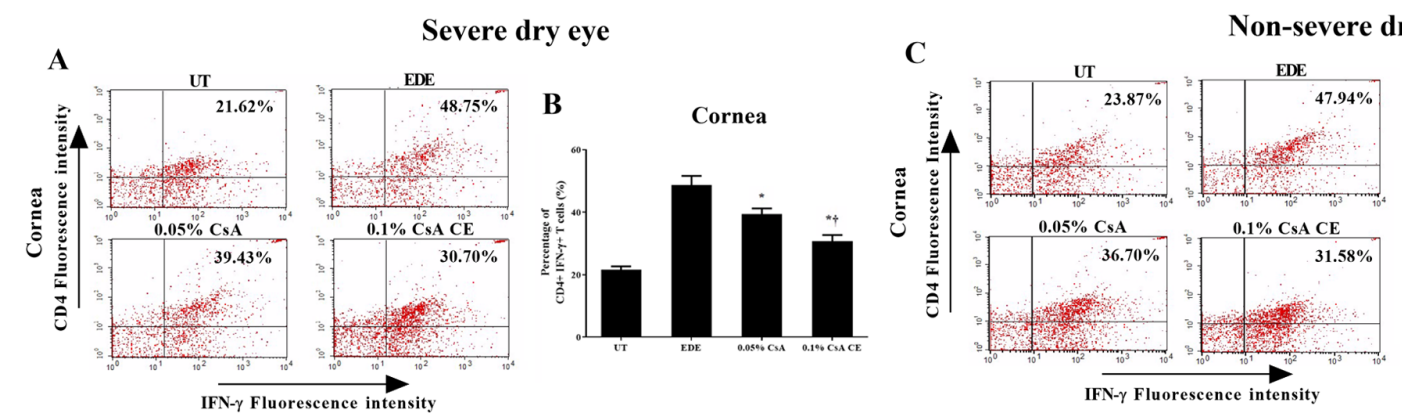

Non-severe dry eye
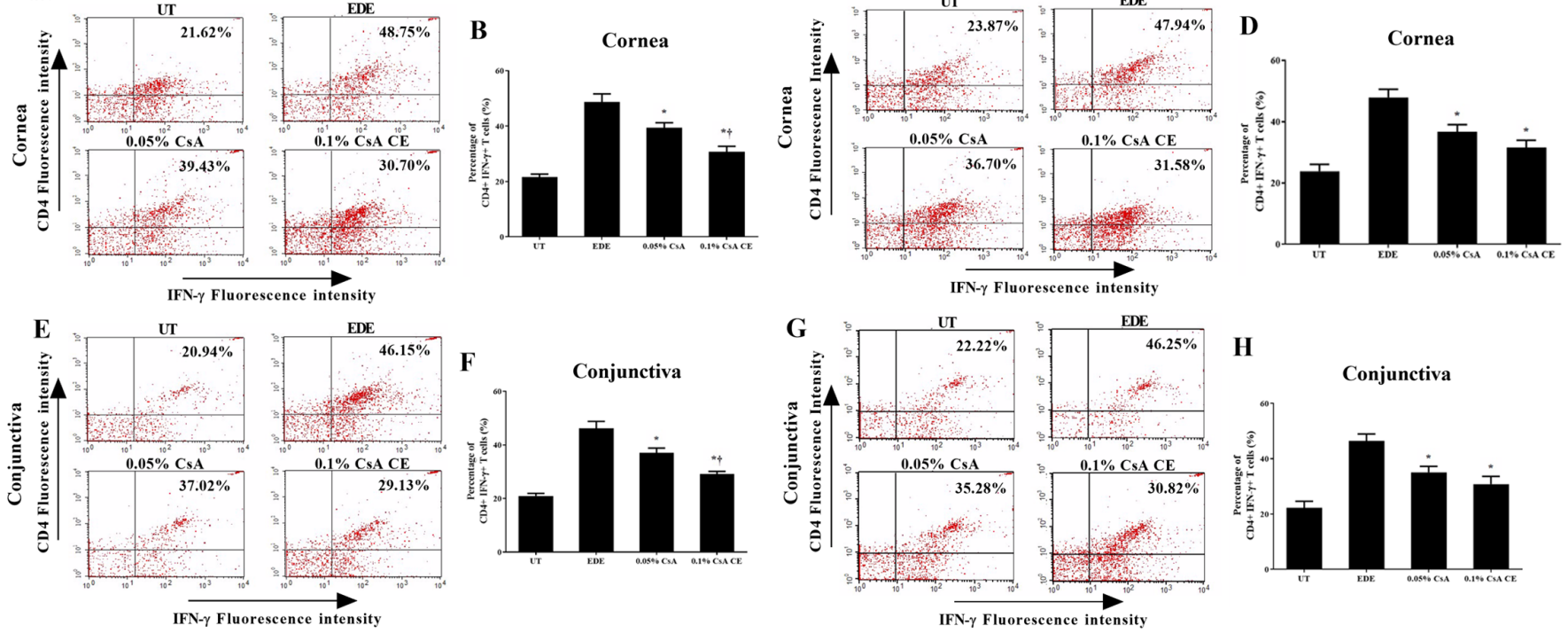

Figure 5. Flow cytometry analysis for $\mathrm{CD} 4^{+} \mathrm{T}$ cells. Percentage of $\mathrm{CD} 4^{+} \mathrm{IFN}-\gamma^{+} \mathrm{T}$ cells in the (A-D) cornea and (E-H) conjunctiva in UT, EDE, $0.05 \%$ CsA emulsion-treated and $0.1 \%$ CsA CE-treated mice from the severe dry eye and non-severe dry eye groups at day $10 .{ }^{*} \mathrm{P}<0.05$ vs. EDE; ${ }^{\dagger} \mathrm{P}<0.05$ vs. $0.05 \%$ CsA. UT, untreated control; EDE, experimental dry eye; CsA, cyclosporin A; CE, cationic emulsion; IFN, interferon- $\gamma$.
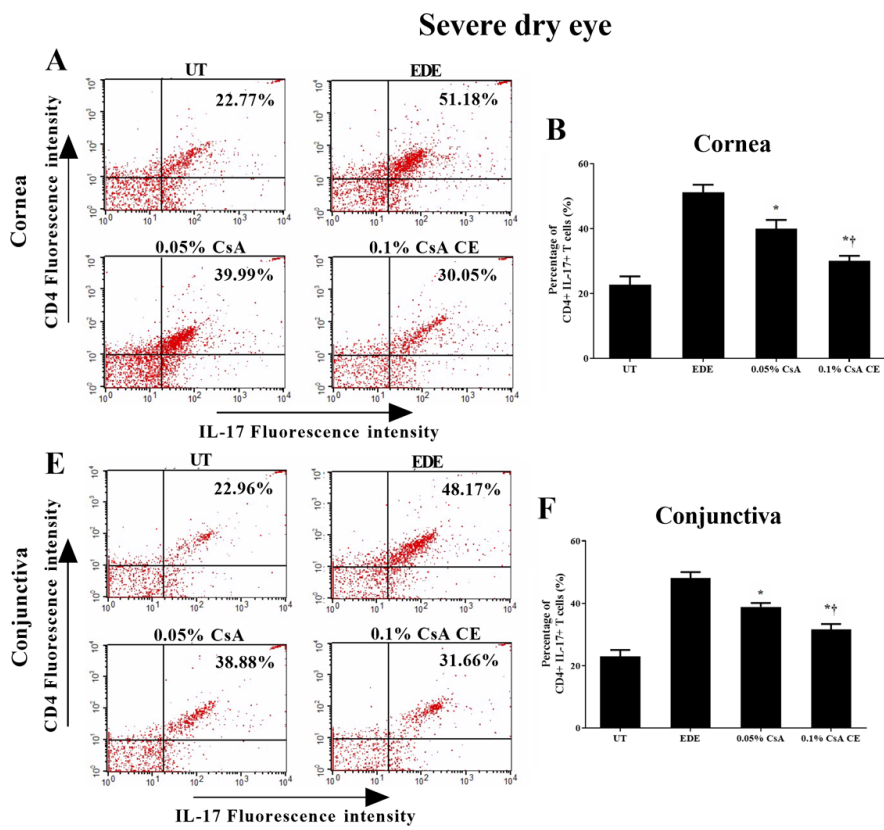
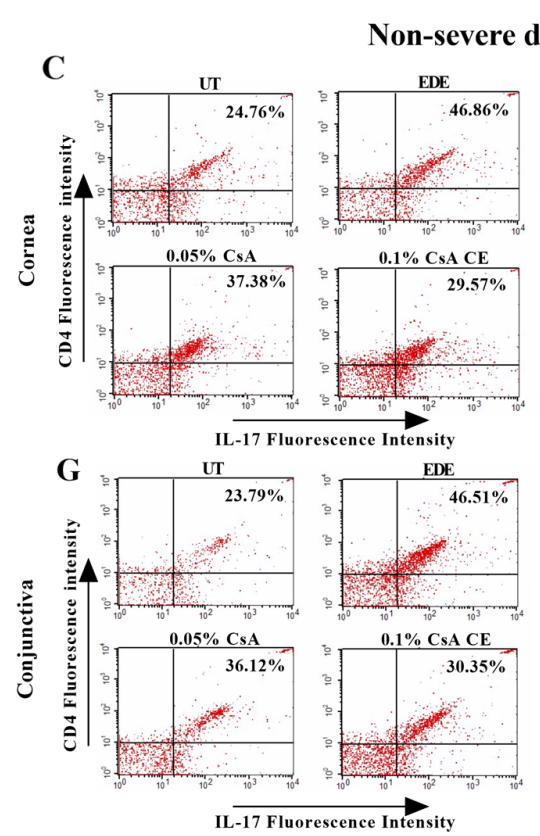

Figure 6. Flow cytometric analysis for $\mathrm{CD}^{+} \mathrm{T}$ cells. Percentage of $\mathrm{CD} 4^{+} \mathrm{IL}-17^{+} \mathrm{T}$ cells in the (A-D) cornea and (E-H) conjunctiva in UT, EDE, $0.05 \%$ CsA emulsion-treated and $0.1 \%$ CsA CE-treated mice from the severe dry eye and non-severe dry eye groups at day $10 .{ }^{*} \mathrm{P}<0.05$ vs. EDE; ${ }^{\dagger} \mathrm{P}<0.05$ vs. $0.05 \%$ CsA. UT, untreated control; EDE, experimental dry eye; CsA, cyclosporin A; CE, cationic emulsion; IL-17, interleukin-17.

\section{Discussion}

Inflammation is a major pathogenic mechanism underlying DE, ultimately resulting in apoptotic cell death. The infiltration of $\mathrm{T}$ cells and proinflammatory cytokines at the ocular surface is known to initiate a cascade of events that leads to the progression of DE indicators and symptoms $(22,23)$. In the absence of adequate treatment methods, the ocular surface is gradually damaged that would eventually lead to SDE, which has a negative impact on the patient's quality of life. The CsA emulsion, which serves as an important agent for
$\mathrm{DE}$ treatment, can inhibit the activation of $\mathrm{CD} 4^{+} \mathrm{T}$ cells by blocking IL-2 production thereby decreasing apoptosis on the ocular surface (24).

In the present study, to evaluate the change in tear film and corneal epithelial damage following CsA emulsion treatment, tear film BUT and CFSs were evaluated in mice with EDE of different severities. Mice treated with $0.05 \%$ CsA emulsion and $0.1 \%$ CsA CE exhibited significantly improved tear volumes, tear film BUTs and CFSs compared with EDE mice in the SDE and NSDE groups. Interestingly, in SDE mice, topical application of $0.1 \% \mathrm{CsA} C \mathrm{CE}$ led to a significantly lower 
A

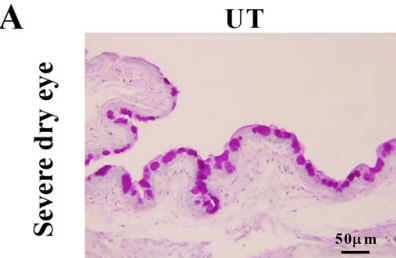

C 50
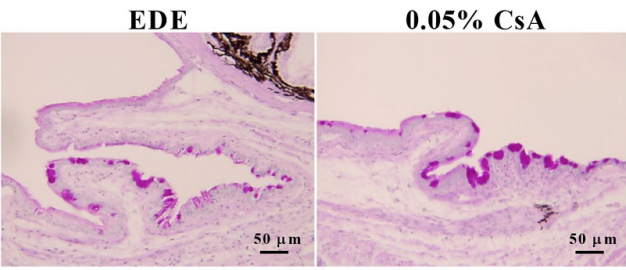

$0.05 \% \operatorname{CsA}$

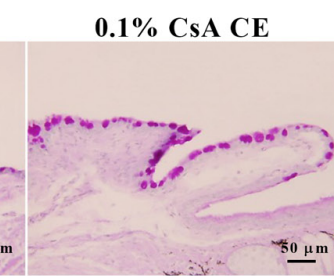

t30

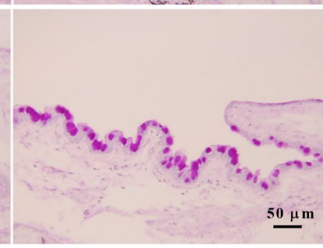

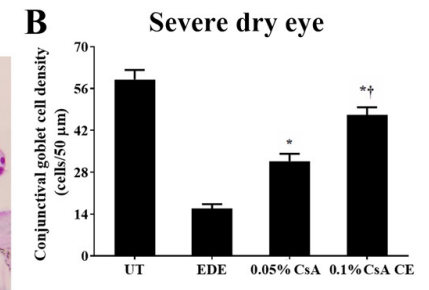

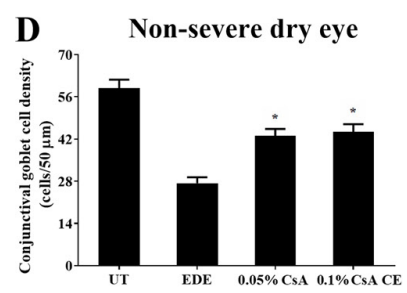

Figure 7. Periodic Acid-Schiff staining for conjunctival goblet cell densities. (A and C) Representative specimens of conjunctiva and (B and D) mean conjunctival goblet cell densities in UT, EDE, $0.05 \%$ CsA emulsion-treated and $0.1 \%$ CsA CE-treated mice from the severe dry eye and non-severe dry eye groups at day 10. Scale bar, $50 \mu \mathrm{m}$. "P<0.05 vs. EDE; ${ }^{\circ} \mathrm{P}<0.05$ vs. $0.05 \%$ CsA. UT, untreated control; EDE, experimental dry eye; CsA, cyclosporin A; CE, cationic emulsion.

A
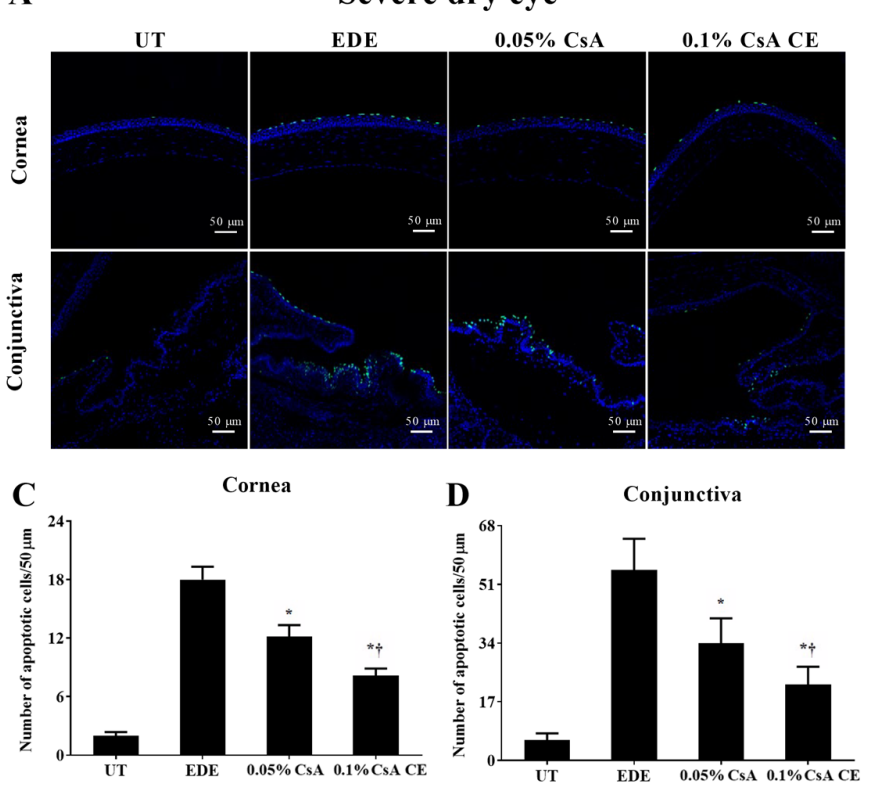

B

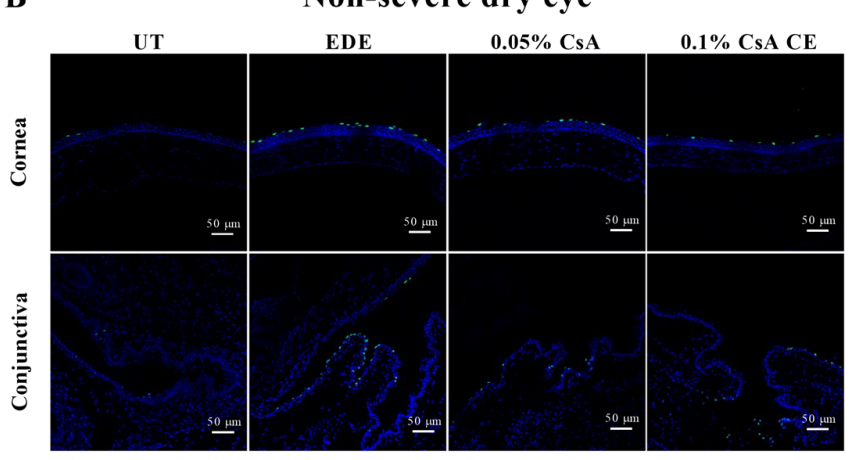

$\mathbf{E}$

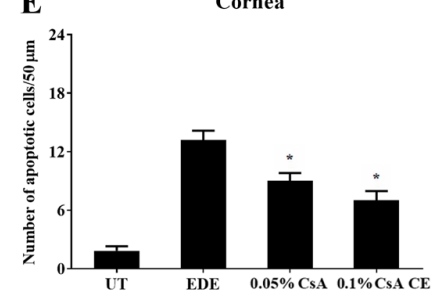

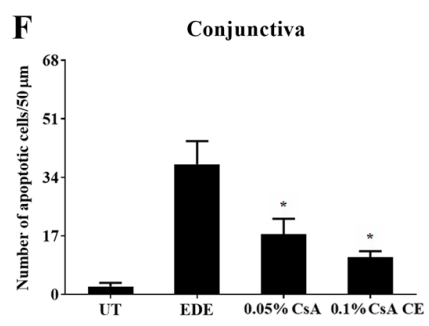

Figure 8. TUNEL staining for apoptosis on the ocular surface. (A and B) Representative pictures of cornea and conjunctiva in the severe dry eye group and in the non-severe dry eye group. Mean numbers of TUNEL-positive cells in the (C and E) cornea and (D and F) conjunctiva of UT, EDE, 0.05\% CsA emulsion-treated and $0.1 \%$ CsA CE-treated mice from the severe dry eye and non-severe dry eye groups at day $10 .{ }^{*} \mathrm{P}<0.05$ vs. EDE; ${ }^{\dagger} \mathrm{P}<0.05$ vs. $0.05 \% \mathrm{CsA}$. UT, untreated control; EDE, experimental dry eye; CsA, cyclosporin A; CE, cationic emulsion.

CFS on the ocular surface compared with that of $0.05 \%$ CsA emulsion. The significant differences between groups in terms of therapeutic effect on SDE could be explained by the cationic property of CsA CE as well as its concentration. This innovative formulation increases the retention time of the nanodroplets on the ocular surface, improving therefore the drug delivery by interacting electrostatically with the negatively charged components of the tear film (25). A previous study reported that CsA CE is well tolerated and effectively improves the signs and symptoms in patients with moderate-to-severe DE to SDE over 6 months, in particular in patients with severe disease who are at risk of irreversible corneal damage (14). Furthermore, previous clinical studies demonstrated that $0.1 \%$ CsA CE improves the CFS, CFS OSDI response and conjunctival expression of human leukocyte antigen DR in SDE cases with keratitis and SS (12-14). Consistently with these previous reports, the results from the present study demonstrated that the application of $0.05 \% \mathrm{CsA}$ emulsion and $0.1 \% \mathrm{CsA} \mathrm{CE}$ both led to improvements in the clinical parameters in EDE mice. In addition, the efficacy of $0.1 \%$ CsA CE was more notable than that of the $0.05 \%$ CsA emulsion in SDE mice.

To investigate the inflammatory changes and cell death on the ocular surface, the expression levels of $\mathrm{NF}-\kappa \mathrm{B}$ and of the inflammatory cytokines TNF- $\alpha$, IL- 6 and IL-17 were evaluated, and the extent of apoptotic cell death on the ocular surface was also explored. In addition, the percentage of $\mathrm{CD}^{+} \mathrm{T}$ cells and conjunctival goblet cell density were also measured. The results demonstrated that mice treated with $0.05 \%$ and $0.1 \%$ CsA CE presented with lower expression of NF- $\kappa \mathrm{B}$ and decreased levels of inflammation on the ocular surface. In addition, CsA-treated 
mice had a reduced number of apoptotic cells on the ocular surface and an increased density of conjunctival goblet cells compared with non-treated groups. Furthermore, in the SDE group, mice treated with $0.1 \%$ CsA CE showed improved results in terms of the reduction in the number of apoptosis cells and the increased density of conjunctival goblet cells compared with mice treated with $0.05 \%$ CsA. The CE may be able to enhance film hydration, lubrication and stability, as the aqueous medium of the emulsion droplets may allow rehydration, and the oily phase replenishes the lipid layer (25-27). In addition, the cationic vehicle of CsA CE itself has been shown to possess anti-inflammatory effects $(28,29)$. Chronic inflammation in the epithelium may promote angiogenesis, invasion and metastasis, and cytokines induce a strong inflammatory response. Furthermore, the TNF/TNF receptor system plays an important role in the induction of apoptotic machinery and inflammation $(30,31)$. Previous studies have reported that blocking inflammatory cytokines can delay the progression of diseases, such as rheumatoid arthritis, multiple sclerosis and inflammatory bowel diseases $(30,32,33)$. In the present study, the levels of inflammatory cytokines, including TNF- $\alpha$, were significantly decreased in the SDE group following treatment with $0.1 \%$ CsA CE. These findings suggested that $0.1 \% \mathrm{CsA} C \mathrm{CE}$ may be effective at reducing inflammation and apoptosis on the ocular surface by downregulating the activation of $\mathrm{NF}-\kappa \mathrm{B}$ and cytokines in SDE compared with $0.05 \%$ CsA emulsion.

Based on the results of the present and previous studies, it can be inferred that both higher CsA concentrations and cationic carriers contributed to the increased therapeutic effect of $0.1 \%$ CsA CE in SDE. However, further studies are required to provide a more detailed comparative analysis of these two parameters. In addition, since DE is a chronic disease, it would be helpful to analyze the long-term therapeutic effects of $0.1 \% \mathrm{CsA} C \mathrm{C}$, and to detect CsA concentration in blood in further experiments.

In summary, the present study demonstrated that topical $0.1 \%$ CsA CE therapy could improve tear film parameters and ameliorate ocular surface injury and inflammation in SDE and NSDE. In addition, $0.1 \%$ CsA CE was more effective in improving corneal epithelial injury and $\mathrm{T}$ cell-mediated inflammation in SDE than topical $0.05 \%$ CsA emulsion.

\section{Acknowledgements}

Not applicable.

\section{Funding}

This study was supported by the Technology Innovation Program (grant no. 20009481) through the Ministry of Trade, Industry \& Energy (MOTIE), Korea, by the Korea Health Technology R\&D project (grant no. HR20C0021050020) through the Korea Health Industry Development Institute (KHIDI) funded by the Ministry of Health and Welfare, Korea, and by the Chonnam National University Hospital Biomedical Research Institute (grant no. BCRI20072).

\section{Availability of data and materials}

The datasets used and/or analyzed during the present study are available from the corresponding author on reasonable request.

\section{Authors' contributions}

KCY designed the experiments and revised the manuscript. RJ, YL and LL performed the experiments. RJ, HJY and JK analyzed and interpreted the data. RJ, YL and HJY drafted the manuscript. KCY and RJ confirm the authenticity of all the raw data. All authors read and approved the final manuscript.

\section{Ethics approval and consent to participate}

The research protocol used in the present study was approved by the Chonnam National University Medical School Research Institutional Animal Care and Use Committee (approval no. CNU IACUC-H-2018-73). Maintenance of animals and in vivo experiments were performed in accordance with the Association for Research in Vision and Ophthalmology statement for the Use of Animals in Ophthalmic and Vision Research.

\section{Patient consent for publication}

Not applicable.

\section{Competing interests}

The authors declare they have no competing interests.

\section{References}

1. Wolffsohn JS, Arita R, Chalmers R, Djalilian A, Dogru M, Dumbleton K, Gupta PK, Karpecki P, Lazreg S, Pult H, et al: TFOS DEWS II Diagnostic methodology report (2017). Ocul Surf 15: 539-574, 2017.

2. Li Y, Cui L, Lee HS, Kang YS, Choi W and Yoon KC: Comparison of $0.3 \%$ hypotonic and isotonic sodium hyaluronate eye drops in the treatment of experimental dry eye. Curr Eye Res 42: 1108-1114, 2017.

3. Yoon KC, De Paiva CS, Qi H, Chen Z, Farley WJ, Li DQ and Pflugfelder SC: Expression of Th-1 chemokines and chemokine receptors on the ocular surface of C57BL/6 mice: Effects of desiccating stress. Invest Ophthalmol Vis Sci 48: 2561-2569, 2007.

4. Pflugfelder SC: Integrating restasis into the management of dry eye. Int Ophthalmol Clin 46: 101-103, 2006.

5. Stapleton F, Alves M, Bunya VY, Jalbert I, Lekhanont K, Malet F, Na KS, Schaumberg D, Uchino M, Vehof J, et al: TFOS DEWS II Epidemiology report (2017). Ocul Surf 15: 334-365, 2017.

6. Baudouin C, Creuzot-Garcher C, Hoang-Xuan T, Rigeade MC, Brouquet Y, Bassols A, Guillemin I, Benmedjahed K and Arnould B: Severe impairment of health-related quality of life in patients suffering from ocular surface diseases. J Fr Ophtalmol 31: 369-378, 2008.

7. Perry HD and Donnenfeld ED: Topical $0.05 \%$ cyclosporin in the treatment of dry eye. Expert Opin Pharmacother 5: 2099-2107, 2004.

8. Schultz C: Safety and efficacy of cyclosporine in the treatment of chronic dry eye. Ophthalmol Eye Dis 6: 37-42, 2014.

9. Deveney T and Asbell PA: Patient and physician perspectives on the use of cyclosporine ophthalmic emulsion $0.05 \%$ for the management of chronic dry eye. Clin Ophthalmol 12: 569-576, 2018.

10. Kim HS, Kim TI, Kim JH, Yoon KC, Hyon JY, Shin KU and Choi CY: Evaluation of clinical efficacy and safety of a novel cyclosporin A nanoemulsion in the treatment of dry eye syndrome. J Ocul Pharmacol Ther 33: 530-538, 2017.

11. Wirta DL, Torkildsen GL, Moreira HR, Lonsdale JD, Ciolino JB, Jentsch G, Beckert M, Ousler GW, Steven P and Krösser S: A clinical phase II study to assess efficacy, safety, and tolerability of waterfree cyclosporine formulation for treatment of dry eye disease. Ophthalmology 126: 792-800, 2019. 
12. Leonardi A, Van Setten G, Amrane M, Ismail D, Garrigue JS, Figueiredo FC and Baudouin C: Efficacy and safety of $0.1 \%$ cyclosporine A cationic emulsion in the treatment of severe dry eye disease: A multicenter randomized trial. Eur J Ophthalmol 26: 287-296, 2016

13. Eroglu YI: A comparative review of Haute Autorité de Santé and National Institute for Health and Care Excellence health technology assessments of Ikervis ${ }^{\circledR}$ to treat severe keratitis in adult patients with dry eye disease which has not improved despite treatment with tear substitutes. J Mark Access Health Policy 5: $1336043,2017$.

14. Baudouin C, Figueiredo FC, Messmer EM, Ismail D, Amrane M, Garrigue JS, Bonini S, Leonardi A and Baudouin C: A randomized study of the efficacy and safety of $0.1 \%$ cyclosporine A cationic emulsion in treatment of moderate to severe dry eye. Eur J Ophthalmol 27: 520-530, 2017.

15. de Oliveira RC and Wilson SE: Practical guidance for the use of cyclosporine ophthalmic solutions in the management of dry eye disease. Clin Ophthalmol 13: 1115-1122, 2019.

16. Yoon KC, De Paiva CS, Qi H, Chen Z, Farley WJ, Li DQ Stern ME and Pflugfelder SC: Desiccating environmental stress exacerbates autoimmune lacrimal keratoconjunctivitis in non-obese diabetic mice. J Autoimmun 30: 212-221, 2008.

17. Yoon KC, Ahn KY, Choi W, Li Z, Choi JS, Lee SH and Park SH: Tear production and ocular surface changes in experimental dry eye after elimination of desiccating stress. Invest Ophthalmol Vis Sci 52: 7267-7273, 2011.

18. Villareal AL, Farley W and Pflugfelder SC: Effect of topical ophthalmic epinastine and olopatadine on tear volume in mice. Eye Contact Lens 32: 272-276, 2006.

19. Pauly A, Brignole-Baudouin F, Labbé A, Liang H, Warnet JM and Baudouin C: New tools for the evaluation of toxic ocular surface changes in the rat. Invest Ophthalmol Vis Sci 48: 5473-5483, 2007.

20. Li Y, Jin R, Li L, Yoon HJ, Choi JH, Park JH, Liu Z, Li W, Li Z and Yoon KC: Expression and role of nucleotide-binding oligomerization domain 2 (NOD2) in the ocular surface of murine dry eye. Invest Ophthalmol Vis Sci 60: 2641-2649, 2019.

21. Yoon KC, Park CS, You IC, Choi HJ, Lee KH, Im SK, Park HY and Pflugfelder SC: Expression of CXCL9, -10, -11, and CXCR3 in the tear film and ocular surface of patients with dry eye syndrome. Invest Ophthalmol Vis Sci 51: 643-650, 2010.

22. The definition and classification of dry eye disease: Report of the Definition and Classification Subcommittee of the International Dry Eye WorkShop (2007). Ocul Surf 5: 75-92, 2007.
23. Baudouin C, Aragona P, Messmer EM, Tomlinson A, Calonge M, Boboridis KG, Akova YA, Geerling G, Labetoulle M and Rolando M: Role of hyperosmolarity in the pathogenesis and management of dry eye disease: Proceedings of the OCEAN group meeting. Ocul Surf 11: 246-258, 2013.

24. Ambroziak AM, Szaflik J, Szaflik JP, Ambroziak M, Witkiewicz J and Skopiński P: Immunomodulation on the ocular surface: A review. Cent Eur J Immunol 41: 195-208, 2016.

25. Lallemand F, Daull P, Benita S, Buggage R and Garrigue JS: Successfully improving ocular drug delivery using the cationic nanoemulsion, novasorb. J Drug Deliv 2012: 604204, 2012.

26. Rabinovich YI, Vakarelski IU, Brown SC, Singh PK and Moudgil BM: Mechanical and thermodynamic properties of surfactant aggregates at the solid-liquid interface. J Colloid Interface Sci 270: 29-36, 2004.

27. Royle L, Matthews E, Corfield A, Berry M, Rudd PM, Dwek RA, Carrington SD: Glycan structures of ocular surface mucins in man, rabbit and dog display species differences 25: 763-773, 2008.

28. Daull P, Guenin S, Hamon de Almeida V and Garrigue JS: Anti-inflammatory activity of CKC-containing cationic emulsion eye drop vehicles. Mol Vis 24: 459-470, 2018.

29. Hwang SB, Park JH, Kang SS, Kang DH, Lee JH, Oh SJ, Lee JY, Kim JY and Tchah H: Protective effects of cyclosporine A emulsion versus cyclosporine A cationic emulsion against desiccation stress in human corneal epithelial cells. Cornea 39: 508-513, 2020.

30. Jurisic V: Multiomic analysis of cytokines in immuno-oncology. Expert Rev Proteomics 17: 663-674, 2020.

31. Jurisic V, Terzic T, Colic S and Jurisic M: The concentration of TNF-alpha correlate with number of inflammatory cells and degree of vascularization in radicular cysts. Oral Dis 14: 600-605, 2008

32. Yang S, Wang J, Brand DD and Zheng SG: Role of TNF-TNF Receptor 2 signal in regulatory $\mathrm{T}$ cells and its therapeutic implications. Front Immunol 9: 784, 2018

33. Pegoretti V, Baron W, Laman JD and Eisel UL: Selective modulation of TNF-TNFRs signaling: Insights for multiple sclerosis treatment. Front Immunol 9: 925, 2018.

This work is licensed under a Creative Commons Attribution-NonCommercial-NoDerivatives 4.0 International (CC BY-NC-ND 4.0) License. 